\title{
The Original Place of the Priestly Manna Story in Exodus 16
}

\section{Joel S. Baden}

(Yale University)

The story of the giving of manna in Ex 16 has long been recognized as composite, comprising both priestly and non-priestly elements. ${ }^{1}$ The priestly text of Ex 16, however, is unusual, in that it contains a startling number of narrative anachronisms. In a recent article in this journal, Ludwig Schmidt argued that the priestly story in Ex 16 is in its proper place, ${ }^{2}$ in response to the opposite claim by Claus Westermann. ${ }^{3}$ Westermann, it should be noted, was by no means the first to make the claim that the $\mathrm{P}$ story in Ex 16 is out of place; this view was common, if not in fact standard, among classical source critics. ${ }^{4}$ In recent scholarship, however, the older view has been ignored or, as in the case of Schmidt and some others, explicitly rebutted. In this paper, I hope to demonstrate that the priestly story is indeed out of place. I will briefly present the source division of Ex 16, enumerate and evaluate the anachronistic elements in the $\mathrm{P}$ story, speculate as to where the story originally stood in the in-

1 For a response to attempts to leave the chapter undivided, cf. B. S. Childs, The Book of Exodus, 1974, 275-276. A. Kuenen, in his article Beiträge zur Hexateuchkritik. VII. Manna und Wachteln (Ex. 16), in: Gesammelte Abhandlungen zur biblischen Wissenschaft, 1894, 276-294, argued that the chapter is essentially from P, with some later expansions; his opinion was accepted by many who followed. For an extensive summary of scholarship, cf. P. Maiberger, Das Manna: Eine literarische, erymologische und naturkundliche Untersuchung, 1983, 9-86.

2 L. Schmidt, Die Priesterschrift in Exodus 16, ZAW 119 (2007), 483-498.

3 C. Westermann, Die Herrlichkeit Gottes in der Priesterschrift, in: Forschungen am Alten Testament: Gesammelte Studien II 1974, 115-137.

4 CF. W. E. Addis, The Documents of the Hexateuch, 1892, II:246; B. W. Bacon, The Triple Tradition of the Exodus, 1894, 83; A. Dillmann, Die Bücher Exodus und Leviticus, 3rd ed., KHAT 12, 1897, 181; J. E. Carpenter and G. Harford-Battersby, The Hexateuch According to the Revised Edition, 1900, II:104-105; B. Baentsch, Exodus-Leviticus Numeri übersetzt und erklärt, 1903, 144-145; A. H. McNeile, The Book of Exodus, 1917, xxii; S. R. Driver, The Book of Exodus, 1918, 144; C. A. Simpson, The Early Traditions of Israel: A Critical Analysis of the Pre-Deuteronomic Narrative of the Hex ateuch, 1948, 188-189. Even U. Cassuto, A Commentary on the Book of Exodus, 1997, 188 , recognized that this story must have originally taken place after the construction of the Tabernacle. 
dependent priestly document, and present a rationale for why the text was moved. I will conclude with a discussion of the important ramifications this analysis has for source-critical theory, in particular for our conceptions of $\mathrm{P}$ and the compilation of the Pentateuch.

The priestly story in Ex 16 begins in vv. 2-3, after the standard P travel notice of v. 1 , and continues in vv. 6-25 before concluding with vv. 31-36. The non-priestly story $(J)$ comprises vv. 4-5 and 26-30.5 Each of the seams between the two sources is marked by a discontinuity or contradiction. In vv. 2-3, the beginning of the $P$ story, the people complain that they have no food. Yet in v. 4, Yahweh tells Moses that he will test the people by means of the bread he will send from heaven, with no reference to any complaint. A test is not a response to a complaint; nowhere else in the various stories of the Israelites complaining, in $\mathrm{P}$ or in any other source, does the divine response come in the form of a test. ${ }^{6}$ Verse 4 is, rather, the start of a new story, in which the bread serves an entirely different purpose. ${ }^{7}$ In v. 6, Moses and Aaron respond directly to the complaint directed to them in vv. $2-3$; there is no mention of a test but rather Moses and Aaron pick up the people's words from v. 3-"you [i.e., Moses and Aaron] have brought us out into this wilderness to starve the whole congregation to death " - and react to them: "you shall know it was Yahweh [i.e., not we] who brought you out from the land of Egypt. “ Thus from vv. 2-3 we have a contradiction in vv. $4-5$ and continuity in $v .6$.

The priestly story continues uninterrupted through v. 25 , at which point we have reached the seventh day, as Moses says of the food left over from the sixth day, "Eat it today, for today is a sabbath of Yahweh. "Yet in v. 26 , it seems that we are back at the beginning of the week: "Six days you shall gather it; on the seventh day, the sabbath, there will be none." This instruction only makes sense as coming before the week has begun laying out what will happen in the next seven days. In fact, when read as the continuation of vv. 4-5, these words become part of Yahweh's initial

5 The use of the siglum $\mathrm{J}$ here (and $\mathrm{E}$ below) signals my adherence to the four-source theory of the composition of the Pentateuch. It will be noted, however, that the analysis presented here of the priestly story and its correct place in the larger priestly narrative does not depend on any particular view of the origins of the non-priestly materials.

6 The concept of Yahweh testing the Israelites, or anyone, is entirely foreign to $P$, as it has no place in the priestly theology, in which everything that happens is already known to and announced by Yahweh - even the root noj does not occur anywhere in P.

7 We may also note that Yahweh's words, הנגי ממטיר, "I am about to rain ", seem to denote initiative, rather than response. speech to Moses. ${ }^{8}$ And v. 27 confirms this, for it begins by bringing the reader from that initial speech directly to the seventh day: $\gg$ On the seventh day ... ${ }^{9}$ Again, there is both contradiction (v. 25/v. 26) and continuity (v. $5 / \mathrm{v} .26)$.

Verse 31 presents another difficulty. "The house of Israel named it manna - - yet in the immediately preceding verses, the manna has not been mentioned. If we read the text sequentially, it appears that what the Israelite are calling manna is the seventh day (from v. 30). ${ }^{10}$ If we look back to v. 26, however, the last verse of the priestly strand, we find that the manna is indeed referred to: "you will not find it today. « Just as we have seen at the other seams, v. 31 contradicts v. 30 - in this case grammatically - but is continuous with v. 25 .

Though the two stories share some elements in common, they are quite different. The brief $J$ story tells of a test of the Israelites' obedience to Yahweh's instructions. ${ }^{11}$ Yahweh tells Moses that he will give the Israelites bread every day, and double the usual amount on the sixth, for on the seventh, the sabbath, there will be no bread (vv. 4-5.26). On the seventh day, however, the people go out to look for it anyway, thereby

8 For a similar editorial phenomenon, cf. Ex 34,28, where it appears in the canonical text that it is Moses who writes the Decalogue on the tablers (see v. 27), but which in the original source (E) refers to Yahweh (see v. 1), and Dtn 31,23, where the subject of וירו appears to be Moses (who is the last subject named, in v. 22), but is in fact Yahweh, as v. 23 is the continuation of vv. 14-15.

9 This chronological disturbance was noted by D. Frankel, The Murmuring Stories of the Priestly School: A Retrieval of Ancient Sacerdotal Lore, VTSup 89, 2002, 74, although only with regard to v. 27 . There is nothing in v. 26 that marks it as having been spoken on the seventh day; in fact it appears quite the opposite.

10 Cf. Dillmann, Exodus, 191; Carpenter and Harford-Battersby, Hexateuch, II:106; Frankel, Murmuring Stories, 74; Schmidt, Exodus 16, 493.

11 In fact, we probably ought to see the beginning of this story in Ex 15,25b-26 (cf. Bacon, Triple Tradition, 84; McNeile, Exodus, xxi; E. Blum, Studien zur Komposition des Pentateuch, BZAW 189, 1990,147-148). "There he tested them " in 15,25b fits well with the theme of the J story in Ex 16,4-5. In 15,26, the introduction of the theme of keeping Yahweh's laws and commandments links thematically and verbally to the end of the $\mathrm{J}$ story in 16,28 , where this is precisely the issue. J, which has no law code (cf. S. Bar-On, The Festival Calendars in Exodus xxiii 14-19 and xxxiv 18-26, VT 48 [1998]

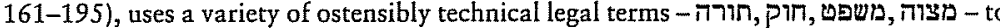
denote general obedience to the will of Yahweh, without implying any formal legislation; aside from $\mathrm{Ex} 15,26$ and 16,28 , see also Gen 18,$19 ; 26,5$. It is possible, as Blum suggests (Studien, 148), that there is a link between the shortage of water in Ex 15,24 and the shortage of food in Ex 16; the J story itself, however, does not explicitly state that the people lacked food. In J, the manna is sent not as a response to a need, but as a test. Thu there is no need to postulate, as some have, that the initial complaint is missing from the J account. Cf. Frankel, Murmuring Stories, 79. 
failing the test (v. 27).12 Yahweh reacts angrily (v. 28), and repeats his instructions regarding the sabbath, this time even more explicitly (v. 29). ${ }^{13}$ And so, the story concludes, the people observed the sabbath (v. 30). The J narrative is an etiology of the Sabbath by way of a divine test. ${ }^{14}$ The story has a concise and clear structure, and is marked by non-priestly language. ${ }^{15}$ In short, this brief narrative is coherent, continuous, and comprehensible on its own terms.

The P story, by contrast, is longer and somewhat complicated. It tells of the people's complaint that they have nothing to eat (vv. 2-3), to which Moses and Aaron react immediately (vv. 6-8). ${ }^{16}$ Moses instructs Aaron to gather the people before Yahweh (v. 9), and when Aaron does so, Yahweh appears (v. 10). Yahweh tells Moses that he will provide meat and bread, thereby demonstrating his power (vv. 11-12). This comes to pass (vv. 13-14). The people do not recognize the bread, and so ask what it is, and Moses tells them that it is the bread Yahweh had promised (v. 15). He then explains the daily process for gathering it (v. 16), which the people follow (vv. 17-18). ${ }^{17}$ Moses further explains that because this bread will appear daily, the people are not to try and keep any until the next day (v. 19). Some do keep it, however, and it rots (v. 20). ${ }^{18}$ The Israelites

12 There is no need to assume that we are missing the description of Moses transmitting Yahweh's words of vv. 4-5.26 to the people; this sort of simple lacuna is typical of J. Cf. Gen 18,17-23; 45,17-21; Ex 2,20-21; 8,1.6-20; 9,1-6.13-20.

13 The transition from first to third person in Yahweh's speech of vv. 28-29 is not uncommon: cf. Gen 9,5-6.16; 18,19; Ex 3,12; 9,1-5; 15,26 (in reverse); 20,5-7; 34,11-14.

14 The division of Carpenter and Harford-Battersby, Hexateuch, II:104-106 and R. E. Friedman, The Bible With Sources Revealed: A New View into the Five Books of Moses, 2003, $146-148$, in which only vv. 4-5 belong to the non-priestly strand, is impossible, as these verses are senseless without a subsequent etiology of the Sabbath.

15 We may note as typical of J the verb המטיר, "rain " (v. 4; cf. Gen 2,5; 7,4; 19,24; Ex 9,18.23); the word for the people, עם (vv. 4.27.30); the verb הOd, "to test " (v. 4), see n. 6 above; the use of legal terminology in a non-specific sense (vv. 4.28 ), see $n .11$ above; the phrase יום יום, "day by day (v. 5; cf. Gen 39,10); and the phrase long " (v. 28; cf. Num 14,11); and as typical of non-P the verb הכין, "prepare" (v. 5 ; cf. Gen 43,16.25; Ex 23,20; Num 23,1.29); and the verb מאן, , refuses (v. 28; cf. Gen 37,35; $39,8 ; 48,19 ; \operatorname{Ex~} 4,23 ; 7,14.27 ; 9,2 ; 10,3-4 ; 22,16$; Num 20,$21 ; 22,13-14)$.

16 The notion in Moses and Aaron's response that the Israelites will see the כבוד יהור the following morning is paralleled in $\mathrm{P}$ by Num 16,5 .

17 Although v. 16 begins with the phrase "this is what Yahweh has commanded ", there is no record in the narrative of Yahweh having actually commanded anything. Moses issuing decrees in the name of Yahweh without the reader being privy to the actual command from Yahweh is not unheard of in P; cf. Num 16,5; 30,2 (with the same phrase).

18 This disobedience in v. 20 in P does not connect to the testing in J: in J the test is entirely about the sixth and seventh days, as v. 5 makes clear; this disobedience in v. 20 occurs on the first day, and has no ramifications other than the people learning the limits of the manna's shelf-life. gather the manna every morning, for by mid-day the sun melts away whatever remains on the ground (v. 21). On the sixth day, however, they find that they have gathered double their usual amount, much to their surprise (v. 22). ${ }^{19}$ Moses explains that this double portion is because of the Sabbath: since the seventh day is the Sabbath, on this sixth day they will gather double, and, contrary to the usual procedure, what they leave until morning will not go bad (v. 23). And so it happens (v. 24). On the seventh day, Moses tells them to eat what they have left from the previous day, for there will be no manna on the ground on the Sabbath (v. 25). The Israelites name this substance manna, and a brief description of it is given (v. 31).20 Moses instructs Aaron to keep some of the manna as an everlasting reminder of Yahweh's power, which Aaron does (vv. 32-34).21 The story concludes by stating that the Israelites ate the manna throughout the forty years in the wilderness, and with a gloss on the meaning of עמר (vv. 35-36).22

The priestly narrative is also coherent, continuous, and comprehensible. As in the I story, each verse builds on the previous and leads to the next, in both content and especially language. It too has a discernible structure. ${ }^{23}$ The issue of Yahweh's power in the initial complaint (vv. 2-3), the responses by Moses and Aaron (vv. 6-8) and Yahweh (vv. 11-12), and the concluding verses (vv. 32-35) frames and thematizes the whole. The detailed procedure for gathering the manna is introduced by the phrase »this is what Yahweh has commanded « (v. 16), as is the de-

19 Whether we should understand there to be some miraculous element to the gathering of the manna or not is a question for the interpretation of $\mathrm{P}$, and does not affect the source division.

20 There is neither contradiction between-the two descriptions of the manna in vv. 14 and 31 , nor is there a doublet of the naming of the manna in vv. 15 and 31 , as many have suggested. The descriptions are complementary, not contradictory: in v. 14 the form of the manna is described; in $v, 31$ the color and taste of the manna are described. CE. WW. Rudolph, Der "Elohist« von Exodus bis Josua, BZAW 68, 1938, 36; Frankel, Murmuring Stories, 77-78. The naming of the manna, despite many statements to the contrary, occurs only once, in v. 31 . In v. 15 , the people ask the question that provides the etymology, and Moses explains what it is - not what it is called. Etymologies are rarer in P than in other sources, perhaps, but they do occur; L. Schmidt, Studien zur Priesterschrift, BZAW $214,1993,42$, points to the naming of Abraham and Isaac in Gen 17.

21 Again there is no notice of Yahweh having given Moses these instructions; see n. 17 above.

22 Whether v. 36 should be attributed to $P$ or to a later glossator, as already J. Wellhausen, Die Composition des Hexateuchs und der historischen Bücher des Alten Testaments, 1885,78 , is debatable, but largely irrelevant.

23 It has been argued that some of these verses are out of order, or that some are attributable to a second priestly hand (cf. Schmidt, Studien, 36-45, a response to these arguments in Childs, Exodus, 278-280, and the scholarship cited in both); for the source division, however, such questions raise no difficulties. All are $\mathrm{P}$, of one variety or another. 
tailed procedure for preserving the manna for all time (v. 32). The central section (vv. 16-25) is framed by the question of what the manna is (v. 15) and what the manna is called (v. 31). The priestly language and style is obvious and thorough-going. ${ }^{24}$

The two stories have in common the connection between the manna and the Sabbath, though little else. ${ }^{25}$ Whether this similarity is an indication that one story was written on the basis of the other, or, as I think more likely, that two independent authors retrojected their contemporary custom of the Sabbath into the wilderness period, is neither possible to answer from the evidence of this chapter nor relevant to the source division. The analysis presented here takes into account both the contradictions and continuities in the text, and results in two complete, distinct, coherent stories.

\section{II}

With the $\mathrm{P}$ and $\mathrm{J}$ narratives separated, we can turn our attention to the anachronisms present in the priestly story. A striking number of elements of P's manna story seem to presuppose elements introduced only later in the priestly narrative. The most obvious of these occur at the end of the chapter, in vv. 34-35. In v. 34, Aaron is said to have placed the jar of manna before the עדת עדת has not yet been given to the Is-

24 For a comprehensive list of priestly terms and phrases in this chapter, cf. Baentsch, Exodus, 145. Verse 16 is also a nice example of the circular inclusio typical of priestly style; cf. M. Paran, Forms of the Priestly Style in the Pentateuch: Patterns, Linguistic Usages, Syntactic Structures (Hebrew), 1989, 49-97.

25 What little language the two stories have in common is entirely due to the content of the narrative, not to any compositional dependency or overlap. Since both describe the Sabbath, it is not surprising that both use the words שביום השישי (though only J uses the phrase יום השביעי, perhaps precisely because only J, introducing the Sabbath for the first time, needs to specify which day it falls on, just as $\mathrm{E}$ uses the phrase for the same reason in $\mathrm{Ex} 20,10 ; 23,12$ ), and since both understand that there is double the usual amoun of manna on the sixth day, both use the word משנה - this being the standard word for "twice as much " in Hebrew. And since both stories require that the Israelites go out to gather the manna, both use the regular Hebrew word for "gather ", לקט (attested in nonpriestly texts in Gen 31,$46 ; 47,14$; Num 11,8, and in priestly texts in Lev 19,9.10; Lev 23,22$)$. All the other words in common in the two stories are perfectly common Hebrew words, with no compositional significance. It should, of course, be emphasized that style and terminology are not adequate bases for source analysis; it is the narrative flow and the historical claims of the stories that take precedence, with the elements of style and terminology playing only a secondary, supporting role.

26 On the עדת, cf. B. J. Schwartz, The Priestly Account of the Theophany and Lawgiving at Sinai, in: M. V. Fox, et al. (eds.), Texts, Temples, and Traditions: A Tribute to Menahem Haran, 1996, 103-134, 126 n. 52 raelites; this occurs at Sinai, while Moses is on top of the mountain (Ex 31,18*27). The עדת belongs in the ark (Ex 25,16), which has also of course not yet been constructed. 28 In v. 35 , the Israelites are said to eat the manna for forty years. Yet at this point in the $\mathrm{P}$ story, there is no reason to think that the Israelites are going to be in the wilderness for forty years; the wandering and the death of the generation of the Exodus is decreed only in the episode of the spies (Num 14,28-35). While it is pos sible to read both of these references as proleptic, they would be the only examples of such in the entire priestly work. ${ }^{29}$

That vv. 34-35 are not proleptic is supported by other anachronisms in Ex 16 that cannot be so described. In v. 33, Moses instructs Aaron to place the manna לפני יתוה, "before Yahweh. "In P this is a technical term, and has a very concrete reference: it means "before the Tabernacle in which Yahweh resides. « 30 That the phrase has a concrete meaning here is clear from the context: Aaron has to place the jar, a physical object somewhere; in Ex 16, however, there is as yet no Tabernacle; there is, in fact, no place that could be described as "before Yahweh." (We may profitably compare the placement of Aaron's staff "before Yahweh " in Num 17,25.) Before the construction of the Tabernacle, Yahweh is not physically present among the people in $\mathrm{P}$.

27 Ex 31,18 is a composite verse. $P$ read here "He gave to Moses, when he finished speakin with him on Mount Sinai, the עדה. " E read "He gave to Moses two tablets, tablets of stone, inscribed with the finger of God." The compiler simply combined the two sentences into one, without repeating the doubled words "he gave to Moses. " Cf. J. S. Baden, I, E, and the Redaction of the Pentateuch, FAT 68, 2009, 283-284. The compiler has combined the עדח and the tablets in 31,$18 ; 32,15 ; 34,29$; cf. Schwartz, Priestly Account, 126-127.

28 Childs, Exodus, 291-292, considers this anachronism to be the result of "a theological point which caused the writer to override the chronological sequence. A jar of manna which is the sign of God's sustaining mercy is kept alongside the tablets of the law. « This reads more as an indication of Childs' theological reading than of P's theological writing, which is elsewhere, as Childs himself notes, strict in its chronology.

29 The argument for prolepsis in the $\mathrm{P}$ account is made by W. H. C. Propp, Exodus 1-18, 1999, 590. In his earlier work, Schmidt, Stùdien, 44 n. 31, suggests that the author of vv. 34-35 (whom he believes to be a later supplementer) cared more about the notion that the manna should be preserved in the Tabernacle than the fact that the Tabernacle did not exist yet. But surely a later hand could have just as easily added a note about the manna's place in the Tabernacle at some point after Ex 40 - perhaps even in Num 11. In his more recent publication, Schmidt, Exodus 16,496, attributes v. $35 \mathrm{a}$ to $\mathrm{P}$, and considers it proleptic.

30 Cf. Ex 16,33; 27,21; 34,34; Lev 1,3 ; Num 16,7.16.17, et al. We must therefore reject the argument of $M$. Noth, Exodus, 1962,137, that the phrase "before Yahweh" "shows that $P$ could not yet name here the concrete sanctuary which is rather thought of as in the future. " On the contrary: the phrase refers directly to the concrete sanctuary. 
It is thus equally confusing when, in v. 9, Moses tells Aaron to have the Israelites "approach before Yahweh. "This too is a technical phrase, elsewhere in $\mathrm{P}$ always having the meaning of approaching the Tabernacle/ Tent of Meeting (Lev 9,5; 16,1). ${ }^{31}$ Before the construction of the Tabernacle, however, it is unclear what the phrase would mean: where, precisely, are the Israelites to be brought? Yahweh has no fixed location without the Tabernacle. This problem is highlighted by the ostensible fulfillment of Moses' instructions in v. 10, where the Israelites turn "toward the wilderness ", where Yahweh appears; since the Israelites are in the wilderness already, what does it mean to turn "toward the wilderness «?

A similar problem obtains in the case of the כבוד יהוד (vv. 7.10), which appears in a cloud before the Israelites. In $\mathrm{P}$, the divine appearance in a cloud is connected with two specific locations: the top of Mount Sinai ( $\mathrm{Ex}$ 24,15b-18a), and the Tabernacle/Tent of Meeting (Ex 40,34-38; Lev 9,23; Num 14,10;16,19; 17,7; 20,6). ${ }^{32}$ The appearance of the כבוד ידוה in the middle of the wilderness in Ex 16, before the construction of the Tabernacle, is unique and at odds with the rest of P. ${ }^{33}$ Indeed, if Yahweh can simply appear in the middle of the wilderness, then it is unclear what purpose Sinai (or the Tabernacle) serves at all.

Almost too obvious to mention is the Sabbath itself, which, despite having been prefigured in creation (Gen 2,1-3), is not actually referred to by name until $\operatorname{Ex} 31,15$, whence virtually all the language in 16,23 is derived. ${ }^{34}$ The law of Ex 31,15 is not based on the narrative of Ex 16 , but rather quite the reverse. ${ }^{35}$

31 It is more commonly used in the hiphil, with the same sense: "to bring something to the Tabernacle/Tent of Meeting. " Cf. Ex 28,1;29,3.10; 40,12; Lev 2,4; 6,7; 8,6, et al.

32 On the detailed parallels among these passages, cf. Westermann, Herrlichkeit.

33 The contention of J.-L. Ska, Introduction to Reading the Pentateuch, 2006, 157, that "YHWH reveals this glory for the first time in Exodus 14 (vv. 4.17-18), when he 'glorifies himself by means of victory over Egypt" confuses the concept of Yahweh's glorification in the eyes of the Egyptians and Israelites and the physical manifestation of Yahweh's כבוד, and does not solve the other anachronisms in the text. E. Ruprecht, Stellung und Bedeutung der Erzählung vom Mannawunder (Ex 16) im Aufbau der Priesterschrift, ZAW 86 (1974), 269-307, 291-298, draws the same connection with Ex 14, but claims that the כבוד יהוד has two different meanings in vv. 7 and 10 (that of v. 7 connecting back to Ex 14, that of v. 10 connecting forward to Sinai), meant to create a theological bridge between the escape from Egypt and Sinai. This interpretation is belied by the clear narrative link between the two: $v .7$ is the prediction of the appearance of Yahweh, and v. 10 the fulfillment. The idiosyncratic claim of J. Van Seters, The Life of Moses: The Yahwist as Historian in Exodus - Numbers, 1994, 187, that the "glory" of Yahweh in Ex 16,7 refers to the gift of manna is to be rejected.

34 We may thus also include in the list of anachronisms Moses' statement in v. 23: "This is what Yahweh said: Tomorrow is a day of rest, a holy sabbath of Yahweh ", as this seems to refer directly to Yahweh's actual speech in Ex 31,13-17. The Sabbath is not intro-
Beyond these clear anachronisms in content, there are also a number of phrases in this story that, because they have to do with the cult or other parts of the Sinai event, do not appear anywhere else in $\mathrm{P}$ before Sinai. These include those noted above - עדח (first in Ex 25,16); לפני יהוה (first in Ex 27,2136); קרב (first in Lev 9,537); כבוד יהוד (first in Ex 24,16) - as well as the verb ל (vv. 2.7.8.9.12) which, though known to other sources as well, is used first by $P$ in Num 14,2 - that is, in the first priestly story after the departure from Sinai - and the Israelite camp (v. 13), which is not mentioned in P until Ex 29,14.

The priestly narrative of Ex 16 does not contain only one anachronism, but an extensive collection of them. Even if there were the occasional anachronism in other $P$ passages - which there are not - the striking number of premature elements in $\mathrm{Ex} 16$ would still stand out and require explanation. The cumulative evidence strongly suggests that this story should have originally stood after the Sinai pericope, not before.

\section{III}

Where, then, should we imagine this episode originally stood in the priestly narrative? All of the technical cultic phrases require that it be some time after Ex 40,34-38, when Yahweh formally inhabits the Tabernacle; the notion of the Israelites complaining in the wilderness requires that it be some time after the departure from Sinai in Num 10,28; and

duced via narrative in $\mathrm{P}$, but through the formal institution of the law in $\mathrm{Ex}$ 31,13-17. The P story of Ex 16 presupposes that the Sabbath has already been instituted, while the $\mathrm{J}$ story introduces it for the first time, and, typically, by way of narrative etiology; cf., e.g., Gen 32,33; Ex 4,24-26.

35 It is not the case, as Van Seters claims, Life of Moses, 187, that for $\mathrm{P} n$ the Sabbath existed since creation. " Rather, the natural division of time on which the religious obligation of the Sabbath is based existed since creation; the concept of the Sabbath itself, and any requirement to observe it, does not exist until it is formally decreed at Sinai. The parallel with the division of the animal kingdom and the kosher laws has long been recognized. Schmidt, Exodus 16, 492, correctly points out that the Sabbath, like circumcision and Passover, is not cultically based, and therefore does not require the Sinaitic legislation in order to be practiced. Yet it should be observed that neither circumcision nor Passover is subsequently mentioned in the Sinai legislation, while the Sabbath is (Ex 31,12-17); Schmidt avoids this problem by stating that the Sabbath laws of Ex 31,12-17; 35,1-3 are a later addition to $P$ (ibid., 483).

36 Although the phrase does occur twice before Ex 27,21, in Ex 6,12.30, in these instances it is used to describe Moses speaking to Yahweh, and has a clearly distinct meaning. Everywhere else in P, "before Yahweh " describes a physical act; that it should be used of speaking only here, in the narrative of the revelation of Yahweh's name to Moses, may indicate the special significance of this moment in the priestly history.

37 In the more common hiphil (see above, n. 31), first in Ex 28,1. 
the reference to the forty years of wandering requires that it be some time after Num 14,28-35, when this sentence was pronounced. The presence of Aaron requires that it be some time before Num 20,22b-29, when Aaron dies, and most likely also before Num 20,1-13, when Aaron's and Moses' deaths are decreed. Thus the only question is whether the episode of the manna came before or after Korah's rebellion in Num 16-17, and it is largely impossible to determine the answer either way. Nevertheless, the range of possibilities is fairly well limited.

When returned to its proper place in the overarching priestly narrative, the story of Ex 16 makes considerably more sense. Not only are the anachronisms no longer a problem, but the conjunction of manna and Sabbath becomes clear. The arrival of the manna is a response to Israel's complaint; but once it has arrived, and is to be provided daily, then the question arises of how the Israelites are to both gather their bread daily and observe the Sabbath law decreed at Sinai. The elaborate explanation of $16,16-2.5$ serves to answer this question. ${ }^{38}$ It should be remembered that in the priestly story the Israelites do not violate the Sabbath. The references to the Sabbath in the priestly story do not introduce it as something new; they rather describe the application of the established Sabbath to the new reality of the daily manna.

When the priestly manna story is removed from Ex 16 , what remains of the priestly narrative from the crossing of the sea in Ex 14 to the theophany at Sinai in $24,15 b-18$ a is little more than a series of travel notices: the Israelites came to Elim (Ex 15,27); from Elim to the wilderness of $\operatorname{Sin}(16,1)$; from the wilderness of $\operatorname{Sin}$ to $\operatorname{Rephidim}(17,1 \mathrm{abo})$; and from Rephidim to Sinai (19,1-2a). ${ }^{39}$ In the context of the priestly narrative as a whole, this simple itinerary makes sense: after the final destruction of the Egyptians, nothing is supposed to happen between Egypt and Canaan except Sinai. All of the events of the wilderness - the rebellion of Korah, Moses getting water from the rock, and, indeed, the episode of the manna - are predicated on the unexpected forty years of wandering. ${ }^{40}$

38 The same question with regard to the agricultural produce of the settled land is addressed in virtually the same terms in Lev 25,20-21: Yahweh will provide extra in the sixth year so that there is enough for the seventh.

39 The separation of the itinerary notice in 16,1 and the manna story in the rest of the chapter addresses Schmidt's claim, Studien, 43-44, that the location of the manna story in the wilderness of Sin had to come before Sinai, because the wilderness of Sin is not on the Israelites' route after Sinai. Cf. Bacon, Triple Tradition, 84: „Vs. 1 of ch. xvi. is the regular formula of $\mathrm{P}^{2}$, unmistakably genuine and in place."

40 Although the Israelites do take two months to travel from Egypt to Sinai, and spend nearly a year at Sinai itself, there is little concern in $\mathrm{P}$ for how the Israelites survived their time in the wilderness. Since this entire period was planned from the beginning, it is pre-
IV

If it is clear enough that the priestly manna story has been moved from its original location in the priestly document, it is necessary to ask why it has been so moved. The answer seems fairly evident: the manna could only be given - for the first time - once. The first giving of the manna is a singular event, and, like all singular events in the Pentateuch, when two sources relate the story, they have been combined into a single account (the flood, the sale of Joseph, the plagues, the destruction of the Egyptians, the spies, et al.). If, according to $J$, the regular appearance of the manna was inaugurated before Sinai, then it would be narratively impossible for the $P$ story to take place any time thereafter - especially as, according to $\mathrm{P}(16,15)$, the people's reaction to the manna makes clear that they have never encountered it before.

This procedure of relocating a text from its original position in its source document, though exceptionally rare, is not unparalleled. The same redactional move takes place in the two well-known examples of Gen 19,29, the P notice of the destruction of the cities of the plain (moved from its original position directly after Gen 13,12aba $\alpha^{41}$ ) and the priestly list of Jacob's twelve sons, containing the notice of Benjamin's birth, in Gen 35,22b-26 (moved from before 31,17-18).42 The similarities between these two cases and that of Ex 16 are apparent. In all three, a singular event is related. In all three, leaving the priestly text in its original location would have resulted in a problematic canonical narrative. In all three, the relocated passage now disrupts its context in the independent priestly narrative. These texts have all been moved in the service of the canonical chronology: the issue in all three is when a given event must have happened, and how many times.

It is further clear why the priestly manna story was moved from its original position somewhere in the middle of Numbers to Ex 16, rather than the J story being moved from Ex 16 to somewhere in the middle of Numbers. First, the manna is mentioned again in J in Num 11, where the people complain that their diet lacks variety $(11,6) .43$ This second

sumed that they should not suffer during it; we know that they had animals and other goods, as the sacrifices in Leviticus 8-9 and the elaborate gifts in Num 7 make clear. The forty years in the wilderness, however, could not have been prepared for, nor is it imaginable that the Israelites could have brought enough food to last that long even if they had known in advance.

41 This was recognized already by B. W. Bacon, The Genesis of Genesis, 1893, 135.

42 Cf., e.g., H. Holzinger, Genesis, KHAT 1, 1898, 185.

43 Num 11 is a composite chapter. To J belong vv. 1-10.13.18-24a.31-34. To E belong vv. 11-12.14-17.24b-30. For this division (if not the assignment to J and E), see Blum, Studien, 83. The clear notion in Num 11 that the people have been eating manna for a long time is further evidence that Ex 16 is not entirely or mostly from P; J must have had 
$\mathrm{J}$ episode presumes that the people have been eating manna for an extended period already. Thus to move J's story from Ex 16 to somewhere after Num 14 would also necessitate moving J's story in Num 11 to somewhere even further after that. ${ }^{44}$ Second, the narrative etiology of the Sabbath in I makes (some) sense as having preceded the formal institution of the Sabbath law in $\mathrm{P}$ (Ex 31,13-17). It is imaginable that the people were given an experience of the Sabbath, even testing its limits, before they were given the official law. The reverse, however, is less believable: if the Sabbath law were already in place, then, it is to be expected, the people would not have considered the possibility of going to gather the manna on the seventh day, as this would have been exprèssly forbidden. Thus the best logical order of the Sabbath etiologies is that preserved in the canonical text by keeping J's manna story in its original location before Sinai.

The recognition that the priestly manna story has been relocated from its original position in the priestly narrative provides an explanation for the anachronisms in the text, but it also speaks to some larger issues in pentateuchal scholarship. First and foremost, it stands as important evidence for $\mathrm{P}$ as an originally independent document, and not a redactional layer If $\mathrm{P}$ were a supplement to the non-priestly text, and the priestly manna story written as a revision and expansion of the J account, then the anachronisms would be inexplicable, as the priestly "redactor « would have known precisely where in the canonical text these insertions were to be placed. ${ }^{45}$ The anachronisms are so consistent throughout the entire

a manna story here as well (cf. Van Seters, Life of Moses, 182). Schmidt's argument a manna story here as well (c. Van Seters, Life of the manna in J before Num 11 (and (Exodus 16,496-497) that there was no mention of the manna in J before Num 11 (and removal of the mention of the manna in Num 11.

44 Thus we cannot accept the suggestion of $M$. Noth, A History of Pentateuchal Traditions, $1972,14,31$ n. 110,32 n. 119 , that the non-priestly materials in Ex 16 "do not owe their present position only to the arrangement of the $\mathrm{P}$ narrative and originally belong within the context of Num. 11 «(14); so too Bacon, Triple Tradition, 83.

45 Levin, Der Jahwist, 1993, 353-354, describes the majority of the chapter as belonging to a series of redactional supplements; the anachronisms are distributed among multiple a seres of 11 so unn hoses, 187, and Blum, Studien, 146-148). Rudolph's claim, "Elohist ", 36, that the anachronisms in vv. $32-34$ are proof that they are redactional is quite backward. Ruprecht, Stellung, 274-278, similarly avoids the problem of the anachronisms in vv. 32-34 by atributing them to a later hand, though without explaining why a late redacto would have creared such obvious chronological problems. Frankel, Murmuring Stories, 96 , surmises that the combination of the priestly and non-priestly stories, with the ref- story, however, that there can be little doubt that it originally stood elsewhere, and the only other context in which it could have existed before its relocation in the canonical text is an independent $P$ document.

Second, the relocation of the priestly manna story contributes to our understanding of the compiler's method. This story (along with the similar examples of Gen 19,29 and 35,22b-26) stands out as a rarity in the Pentateuch. In almost no other places does it seem that the compiler relocated passages from their original locations in their source documents. This is evident not primarily from the canonical text, which reads more smoothly as a result of the compiler's work, but rather from the individual sources. When read in isolation, the sources progress in perfect chronological order - with the exception of these parts of $\mathrm{P} .46$ This observation speaks to the compiler's fidelity to his sources, not only in their content, but in the order of their content. Only when faced with a singular event that takes place at two different times in two different sources was the compiler forced to move a text. And even when he did so, he did not alter the content of the passage. ${ }^{47}$ It is this insistence on retaining the words of the sources that allows us to recognize the anachronisms in Ex 16; had the compiler had the freedom to alter his sources at will, these presumably would have been removed. 48

The example of Ex 16 thus highlights the two main roles of the compiler: the preservation of his sources as much as possible, both in content and order, and at the same time the creation of a single canonical story,

erences to the Tabernacle, occurred "outside of the present Pentateuchal framework." Frankel, however, offers no plausible scenario in which such an independent textual combination could have taken place.

46 Perfect chronological order does not mean perfect continuity. It is admitted that there are gaps of varying sizes in all three sources $J, E$, and $P$. Yet the sources are still chronologically ordered, with each story, even, for the most part, each verse, following temporally that which precedes it. The gaps may cause holes in this chronology, but they do not undermine it.

47 The one probable exception to this is in 16,10 , where the Israelites turn "toward the wilderness. "As we have already noted, this phrase makes little sense even in its present context. It seems likely, then, that the $\mathrm{P}$ story originally had "toward the Tent of Meeting " here, as in Num 17,7. CF. Addis, Documents, II:247, et al. Perhaps connected with this is the last word of v. 2, במרבר, "in the wilderness «; it is possible that the original priestly narrative began with a specific location along the post-Sinai itinerary that had to be adjusted here by the compiler.

48 We may also note that the relocation of the priestly text of Ex 16 (and Gen 19,29; $35,22 \mathrm{~b}-26$ as well) stands as a rebuttal to the relatively common claim in documentary scholarship that the compiler favored the priestly text over the non-priestly. This view, suggested by J. Wellhausen, Prolegomena to the History of Israel, 1994, 332, and formalized by Noth, Pentateuchal Traditions, 12, can hardly accommodate the disruption of the strict priestly chronology in favor of the non-priestly text. 
in which events that could not happen twice do not happen twice. Chronological order was the determining factor for the compiler, even as it is the chronological discontinuity of the priestly manna story that allows us to recognize what the compiler has done.

The common view in classical scholarship that the priestly story of the manna in Ex 16 has been moved from its original location in the priestly source has fallen out of favor in the last fifty years and was even explicitly rejected in an article by Ludwig Schmidt in this journal. This paper provides a new source division for Ex 16; lays out the evidence suggesting that the priestly story is indeed out of place; presents arguments for where it originally stood and why it has been moved; and offers reflections on how this analysis affects our view of the priestly materials and the compilation of the Pentateuch.

Selon l'opinion classique de la recherche, Ex 16, avec le récit de la manne, ne se trouve plus à sa place originelle à l'intérieur du code sacerdotal $(P)$. Cette position n'a plus guère été défendue durant ces 50 dernières années et elle a été clairement rejetée récemment par une étude de Ludwig Schmidt dans cette revue. Cette étude présente une nouvelle analyse des sources pour Ex 16: il en ressort que le récit sacerdotal ne se trouve effectivement pas à sa place originelle; les arguments en faveur de l'endroit où le récit originel se trouvait et pourquoi il a été déplacé sont présentés; et livre enfin ses réflexions sur notre compréhension du matériau sacerdotal et sur la compilation du Pentateuque.

Nach der klassischen Forschungsansicht findet sich Ex 16 mit der Erzählung zum Manna nicht mehr an seiner ursprünglichen Stelle innerhalb der Priesterschrift. Diese Position wurde in den letzten 50 Jahren kaum mehr vertreten und vor kurzem in der ZAW ausdrücklich durch Ludwig Schmidt zurückgewiesen. Dieser Artikel präsentiert eine neue Quellenanalyse für Ex 16. Dábei wird vorgeführt, dass die priesterliche Erzählung tatsächlich nicht an ihrem ursprünglichen Ort steht; es werden Gründe für die ursprünglich andere Platzierung und für die erfolgte Umstellung benannt. Zugleich werden die Folgen dieser These für unser Verständnis des priesterschriftlichen Materials und für die Entstehung des Pentateuchs erwogen. 